\title{
İncir Çekirdeği Ununun Mufinin Fiziksel, Kimyasal, Tekstürel ve Duyusal Kalitesi Üzerine Etkisi
}

\section{Hande ÖZKAN ${ }^{* 1}$, Hülya GÜL ${ }^{1}[$}

\author{
${ }^{1}$ Süleyman Demirel Üniversitesi, Mühendislik Fakültesi, Gıda Mühendisliği Bölümü, Isparta
}

Öz: Bu çalışmada; incir çekirdeği ununun (içU) mufin üretiminde kullanılarak mufinlerin kalitesine ilişkin özelliklerinin artııııması amaçlanmıştır. Bu amaçla içU mufin üretiminde 4 farklı oranda (buğday unuyla yer değiştirmeye göre \%0, \%10, \%20, \%30) kullanılmıştır. içU ilave edilerek üretilen mufinlerin bazı kimyasal, fiziksel, tekstürel ve duyusal özellikleri belirlenmiştir. IÇU oranı arttıkça mufinlerin kül, nem, toplam diyet lif içerikleri artmış, hacim, spesifik hacim, simetri indeksi gibi yapısal özellikleri azalmış, mufinlerin kabuk ve iç kesit rengi oran artışına bağı olarak koyulaşmışır. \%20 içU kullanım düzeyine kadar kadar mufinlerin tekstürel ve duyusal özelliklerinde olumsuz bir etki saptanmamış, ancak \%30 düzeyine çıkıldı̆̆ı zaman bu özellikler olumsuz etkilenmiştir. Tüketici açısından \%20 içU katkılı mufin kabul edilebilir olmuştur. Tüm değerlendirmeler göz önüne alındığında içU’nun \%20 takviye düzeyine kadar fonksiyonel olarak eklenebileceği sonucuna varılmıştır.

\section{Anahtar kelimeler: Ficus carica linn, fonsiyonel gıda, diyet lif, reolojik}

\section{Effects of Fig Seed Flour on Physical, Chemical, Textural and Sensory Quality of Muffin}

\begin{abstract}
In this study; It is aimed to increase the quality characteristics of muffins by using fig seed flour (FSF) in muffin production. For this purpose, FSF has been used at 4 different rates (0\%, 10\%, 20\%,30\% replacement with wheat flour) in the production of muffin. Some chemical, physical, textural and sensory properties of the muffins produced by adding FSF were determined. As the FSF ratio increased, the ash, moisture, total dietary fiber contents of the muffins increased, structural properties such as volume, specific volume, symmetry index decreased, and the crust and crumb color of the muffins became darker due to the increase of FSF level. There was no negative effect on the textural and sensory properties of muffins up to 20\% FSF usage level, but when the level was increased to 30\%, these properties were negatively affected. From the consumer point of view, 20\% FSF added muffin was acceptable. Considering all the evaluations, it has been concluded that the FSF can be added in the production of muffins functionally up to $20 \%$ suplementation level.
\end{abstract}

Keywords: Ficus carica linn, functional food, dietary fiber, rheological

\section{GiRiş}

İncir, Latince ismiyle Ficus carica linn, Moraceae familyasına ait bir meyvedir ve dünya çapında yetiştirilen önemli bir mahsuldür. Güneybatı Asya ve Doğu Akdeniz bölgelerinde yetiştirilir. Temmuz ve Ağustos aylarında hasat edilir. Yüksek miktarda şeker, enerji kaynağı, fenolik bileşikler ve vitaminler gibi antioksidan bileşenleri içerir (Herranz ve ark., 2017). Türkiye'de 84,879 ha alanda incir üretimi yapılmakta olup, 10,052 adedi meyve veren olmak üzere, toplam 11,172 adet incir ağacı bulunmaktadır. Bu ağaçlardan elde edilen taze incir miktarı 2020 yılı verilerine göre 310,000 ton olmuştur (Anonim, 2020).

Besin değeri yüksek bir ürün olan incir, şeker, özellikle glukoz ve fruktoz, ve organik asitler bakımından zengindir, ancak sodyum ve yağ içermez. Protein miktarı birçok meyvenin iki katından daha fazladır. Diğer meyvelerle karşılaştırıldığında kalsiyum, bakır, magnezyum, potasyum ve kükürt bakımından birinci; enerji, pantotenik asit, riboflavin, tiamin ve piridoksin bakımından ikinci sırayı aldığı görülür (Pereira, 2017).

İncir çekirdeği yüksek orandaki lif içeriği sayesinde kolesterolün kana karışmadan atılmasını sağlar. Kalp ve damar hastalıklarına karşı vücudu korur. Lif içeriği sindirim sistemini güçlendirir. İncir çekirdeği $E$ ve $D$ vitaminleri bakımından oldukça zengindir. İncir çekirdeğinde bulanan $E$ vitamini metabolizma açısından koruyucu bir etkiye sahiptir,

vücuttan toksinlerin atılmasında faydalı olduğu
bilinmektedir. Yapılan çalışmalar ile omega-3, omega-6, omega-9 yağ asitleri bakımından çekirdeğin zengin olduğu belirtilmiştir. Incir çekirdeğinin anne sütünü arttırıcı etkisi gözlemlenmiştir. İncir çekirdeği enerji deposudur, vücuda enerji sağlar. Kolesterol seviyesini düşürücü etkisinden dolayı, şeker hastalarının ve kilo sorunu olanların kullanması oldukça faydalıdır (Ulutürk, 2018).

Gıda sanayinin önemli bir alt sektörü unlu mamuller ve pastacılıktır. Toplumların gelişmesine bağlı olarak sektörün gelişimi artmakta ve artmaya devam etmektedir. Günümüzde tüketiciler hem besin değeri açısından zengin hem de insan sağlığına olumlu etkileri bulunan gıdaların tüketimine ilgi göstermektedir. Unlu mamuller arasında önemli bir yeri olan mufin üretimi de artmakta ve farklı formülasyon ve şekillerde üretilmeye devam etmektedir (Akbaş, 2009). Mufinin kalitesini arttırmak amacıyla birçok

*Sorumlu Yazar: hande57ozkan@qmail.com Bu çalışma yüksek lisans tez ürünüdür ve Süleyman Demirel Üniversitesi Bilimsel Araştırma Projeleri Koordinasyon Birimi tarafından desteklenmiştir (Proje No: FYL-20196940)

Geliş Tarihi: 27 Ağustos 2020

Kabul Tarihi: 24 Haziran 2021 
çalışma yapılmıştır. Bunlardan yağsız ayçiçek çekirdeği unu (Grasso ve ark., 2020), deniz yosunu unu (Mamat ve ark., 2018), fıstık unu (Akter ve Alim, 2018), karabuğday ve amarant unu (Pineda ve ark., 2018), nar çekirdeği tozu (Noğay, 2014), domates tozu (Yadav ve ark., 2018), frenk üzümü tozu (Llorca ve ark., 2019), kimchi (Heo ve ark., 2019), yabanmersini (Camire ve ark., 2018), tatlı bakla ve soya fasülyesi unu (Frank ve ark., 2018), vişne tozu (Bajerska ve ark., 2016), darı unu (Gupta ve ark., 2015) vb. ile mufinin protein, yağ, lif gibi özellikleri arttırılmıştır.

Domates tozuyla yapılan çalışmada mufinin protein, diyet lif ve mineral içeriğini arttırdı̆̆ı, mufinin yumuşak bir dokuya sahip olduğu vurgulanmıştır (Yadav ve ark., 2018). Vella ve ark. (2015) yaptıkları çalışmada soya ununun mufinin nem ve diyet lif düzeyini arttırdığını, protein içeriğinde önemli bir değişiklik olmadığını belirtmişlerdir.

Yapılan literatür taramasında ulusal ve uluslararası düzeyde bilimsel anlamda ve sanayi açısından incir çekirdeği ununun mufin üretiminde kullanımına yönelik bir çalışmaya rastlanmamıştır. Bu nedenle bu çalışmada; incir çekirdeği ununun mufin üretiminde kullanılabilirliğinin araştırılması, üretilen mufinlerin bazı kimyasal, fiziksel besinsel, tekstürel ve duyusal kalite özelliklerinin saptanması, içU'nun mufin örneklerine ilave edilmesiyle hem lezzetli hem besleyici fonksiyonel bir ürün geliştirilmesi amaçlanmıştır.

\section{MATERYAL VE YÖNTEM}

Çalışmada kullanılan özel amaçlı buğday unu Hediye Un Fabrikası'ndan (Isparta); şeker, margarin, yağsız süt tozu, pastörize yumurta, kabartma tozu ve süt piyasadan temin edilmiştir. İncir çekirdeği unu (IÇU), kurutulup öğütülüp un formatına getirilmiş halde Bir Numaralı Bitkisel Ürünler'den (Aydın) temin edilmiştir.

\section{Un Analizleri}

Özel amaçlı buğday unu ve içU'da nem (AACC Method, 4401.01, 2000), Kül (AACC Method, 08-01.01, 2000), protein (AOAC Method, 950.36, 2000), toplam yağ (AOAC, 1990), toplam diyet lif (AACC Method, 32-07.01, 2000) analizleri yapılmıştır. Renk değerleri ( $L$, a ve b) Minolta CR-410 cihazı ile ölçülmüştür.

\section{Mufin Üretimi}

Mufin üretiminde Çizelge $1^{\prime}$ de verilen hamur formülü kullanılmıştır. Üretim İpek (2017) tarafından kullanılan yönteme göre yapılmıştır. Pastörize yumurtalar el mikserinde (Tefal Smart, Türkiye) 1. devirde 2 dakika çırpıldıktan sonra, su ve şeker sırayla ilave edilerek 1. devirde 1 dakika çırpılmıştır. Sonra margarin ilave edilip 1. devirde 1,5 dakika daha çırpıldıktan sonra diğer bileşenler eklenerek 1. devirde 1 dakika çırpıldıktan sonra ek olarak 2. devirde 1 dakika daha çırpılmıştır. Elde edilen hamur karışımı 35 gr mufin pişirme kağıtlarına tartılarak 12'li mufin kalıplarına koyulmuştur. Siemens marka set üstü fırının orta 34 katında $200{ }^{\circ} \mathrm{C}$ 'de 20 dakika pişirilmiştir. Fırından çıktıktan sonra 20 dakika kalıpta, 40 dakika kalıp dışında soğumaya bırakılmıştır. Soğuyan örneklere analizler uygulanmıştır. içU mufin hamuruna 3 ayrı oranda (\%10, \%20, \%30) ilave edilmiştir.

\begin{tabular}{ll} 
Çizelge 1. Mufin hamuru formülasyonu \\
\hline Bileşenler & Miktar (g) \\
\hline Un & 100 \\
Şeker & 80 \\
Yumurta & 60 \\
Margarin & 60 \\
Su & 35 \\
Yağsız süt tozu & 7.5 \\
Tuz & 3 \\
IÇU & Özel amaçlı buğday unuyla yer \\
& değiştirme metoduna göre \%10, \\
& \%20 ve \%30 oranlarında ilave \\
& edilmiştir. \\
\hline
\end{tabular}

\section{Fiziksel ve Kimyasal Özelliklerin Belirlenmesi}

Belirli oranlarda içU ile üretilen mufin örneklerinin hacim, simetri ve tekdüzelik indeksleri ile büzülme değeri ve toplam hacim indeksi (AACC Metot 10-91.01; AACC, 2000) ve pişme kaybı değerleri belirlenmiştir (İpek ve Dizlek, 2018). Mufin örneklerinin hacim değerleri kuşyemi ile yer değiştirme metoduna göre belirlenmiştir. Belirlenen hacim değerleri mufin örneklerinin pişmiş ağırlıklarına bölünerek spesifik hacim değerleri hesaplanmıştır (Noğay, 2014).

Mufinlerin temel olarak nem (AACC Method, 44-01.01, 2000), Kül (AACC Method, 08-01.01, 2000), protein (AOAC Method, 950.36, 2000), toplam yağ (AOAC, 1990), toplam diyet lif (AACC Method, 32-07.01, 2000), su aktivitesi (Novasina, Lab Touch-aw, Lachen, İsviçre) (Ulutürk, 2018) değerleri belirlenmiştir.

\section{Renk Özelliklerinin Belirlenmesi}

Renk ölçümü Minolta Tristumulus Colorimeter (CR-410) cihazı ile yapılmıştır. Numunelerde üç farklı bölgeden ölçüm yapılmış ve renk bileşenleri $L$, a ve $b$ değerleri belirlenmiştir. Renk skalası; L değeri [(0)Siyah - (100) Beyaz], a değeri [(+) kırmızı, (-) yeşil] ve b değeri [(+) sarı, (-) mavi] olarak kullanılmıştır (Demirekin, 2019).

\section{Tekstür Özelliklerinin Belirlenmesi}

Mufin örneklerinin TPA değerleri TA-XT PLUS cihazında (TAXT Plus, İngiltere) $36 \mathrm{~mm}$ 'lik silindir prob (TA4/1000) kullanılarak belirlenmiştir. Mufin örnekleri elektrikli bıçak kullanılarak enine kesilmiş ve üst kabuk kısımları atılarak ölçümler taban kısmıyla yapılmıştır. TPA parametrelerinden; sertlik, esneklik, yapışkanlık, sakızımsılık, çiğnenebilirlik ve sıkılık değerleri ölçülmüştür. Ölçümler üç paralel ve üç tekerrür şeklinde yapılmış ve elde edilen ortalama değerler verilmiştir. Doku parametrelerinin hesaplanması için $5 \mathrm{~kg}$ 
yük hücresi kullanılmıştır. Analiz parametreleri: Ön test hızı $1.0 \mathrm{~mm} / \mathrm{s}$, test hızı $1.0 \mathrm{~mm} / \mathrm{sn}$, test sonrası hız $1.0 \mathrm{~mm} / \mathrm{sn}$, mesafe mufin yüksekliğinin yarısı kadardır.

\section{Duyusal Değerlendirme}

Mufinlerin duyusal değerlendirmesi 10 kişilik bir panelist grubu tarafından yapılmıştır. Öncesinde panelistlere mufinlerin duyusal değerlendirme kriterleri hakkında bilgi verilmiştir. Rastgele numaralandırılan örnekler panelistlere ayrı ayrı sunulmuş, bir mufin örneğinden diğerine geçerken panelistlere içme suyu verilmiştir. Duyusal kalite kriterleri 1'den 5'e kadar puanlama sistemine göre yapılmıştır (5 puan: çok iyi, 4 puan: iyi, 3 puan: kabul edilebilir, 2 puan: yeterli değil, 1 puan: kötü). Mufin örnekleri dış ve iç renk, gözenek yapısı, tekstürel özellikler, koku, aroma, tat/lezzet ve genel beğeni özellikleri açısından değerlendirilmiştir (Ulutürk, 2018).

\section{İstatistiksel Değerlendirme}

Farklı oranlarda içU ilave edilerek üretilen mufinlerin tüm özelliklerine ilişkin olarak elde edilen veriler, "SPSS" paket programı (SPSS, version 23.0 for Windows, SPSS Inc., Chicago, ABD) kullanılarak öncelikle varyans analizi (ANOVA) uygulanmış, sonra önemli bulunan değerler Duncan çoklu karşılaştırma testine tabi tutulmuştur.

\section{BULGULAR VE TARTIŞMA}

\section{Unların Bazı Kompozisyonel Özellikleri}

içU ve özel amaçlı buğday ununun kimyasal ve fiziksel özellikleri Çizelge 2'de verilmiştir. IÇU'nun nem değeri $\% 6.13$, kül değeri \%3.1, protein değeri \%1.7, toplam diyet lif içeriği \%75.6, toplam yağ değeri \%18.37, su aktivitesi (aw) değeri 0.475 olarak belirlenmiştir.

Çizelge 2. Un özelliklerine ilişkin değerler

\begin{tabular}{lcc}
\hline Özellik & $\begin{array}{c}\text { Özel amaçlı } \\
\text { buğday unu }\end{array}$ & içU \\
\hline Nem (\%) & 12.5 & 6.13 \\
Kül (\%) & 0.2 & 3.1 \\
Protein (\%) & 8.1 & 1.7 \\
Toplam diyet lif (\%) & - & 75.6 \\
Toplam yağ (\%) & 0.02 & 18.37 \\
Su aktivitesi (aw) & 0.544 & 0.475 \\
L değeri & 89.13 & 47.4 \\
a değeri & 0.56 & 7.59 \\
b değeri & 10.16 & 13.0 \\
\hline
\end{tabular}

ÖZKAN H, GÜL H Yapılan bir çalışmada iki farklı türdeki incir çekirdeklerinin nem değerlerinin \%7-10 arasında, kül değerlerinin ise \%1.04-4.1 arasında değiştiği belirtilmiştir (Yazıcı, 2016). Taş (2019) incir çekirdekleri üzerine yaptığı çalışmada protein içeriğinin \%14.74-15.07 arasında olduğunu belirtmiştir. Çalışmada kullanılan içU'nun protein (\%1.7) ve diyet lif içeriği (\%75.6) dikkate alındığında mufin üretiminde kullanılan farklı katkılara göre daha avantajı olduğu sonucuna ulaşılmıştır.

Özel amaçlı buğday ununun nem ve kül değerleri sırasıyla $\% 12.5$ ve $\% 0.2$, protein içeriği \%12.5, toplam yağ değeri $\% 0.02$, su aktivitesi değeri 0.544 olarak bulunmuştur. Bir çalışmada buğday ununun nem değerinin \%13.04, kül değerinin \%0.77 olduğu belirtilmiştir (Akter ve Alim, 2018). Pineda ve ark. (2018) amarant ve karabuğday un karışımıyla yaptığı çalışmada buğday ununun protein içeriğini \%11.2, yağ değerini \%1.5 olarak bildirmişlerdir. Yapılan başka bir çalışmada su aktivitesi değeri 1.02 olarak bulunmuştur (Llorca ve ark., 2019).

IÇU’nun L değeri (47.4) buğday ununa (89.13) göre daha düşük yani daha koyu, kırmızılık ve sarılık değerlerinin ise (sırasıyla 7.59 ve 13.0) buğday ununa göre (sırasıyla 0.56 ve 10.16) daha yüksek olduğu belirlenmiştir.

\section{Fiziksel ve Kimyasal Özellikler}

Üretilen mufinlerin fiziksel özelliklerinden hacim, spesifik hacim, pişme kaybı, hacim indeksi, toplam hacim indeksi değerleri Çizelge 3'te simetri indeksi, üst ve alt büzülme ve tekdüzelik indeksi değerleri Çizelge 4'te verilmiştir. içU ilavesi mufinlerin hacim, spesifik hacim ve hacim indeksi değerleri üzerinde istatistiksel olarak önemli farklar oluşmuştur. Mufinlerde hacim ve hacim indeksi içU oranı arttıkça azalma göstermiştir. Değerler arasında belirgin bir farkın oluşmadığı görülmüştür. Dizlek ve Altan (2013) hacim ve hacim indeksi arasında doğrusal bir ilişki olduğunu belirtmişlerdir. Buna göre hacim ve hacim indeksi değerlerini uyumlu olduğu belirlenmiştir. Toplam hacim indeksi değerleri incelendiğinde içu oranı arttıkça değerlerde düşüş olduğu görülmüştür. Noğay (2014) yaptığı çalışmada benzer sonuçlar elde etmiş, nar çekirdeği tozunun mufine ilavesi sonucu mufinlerin hacim ve spesifik hacim değerlerinde olumsuz bir etki oluşturmadığını belirtmiştir. Mamat ve ark. (2018) deniz yosunu unu ilave

Çizelge 3. Mufinlerin bazı fiziksel özelliklerine ait değerler

\begin{tabular}{lccccc}
\hline $\begin{array}{l}\text { içU oranı } \\
(\%)\end{array}$ & Hacim & $\begin{array}{c}\text { Spesifik hacim } \\
\left(\mathbf{c m}^{\mathbf{3}} \mathbf{g}^{-\mathbf{1}}\right)\end{array}$ & $\begin{array}{c}\text { Hacim indeksi } \\
(\mathbf{m m})\end{array}$ & $\begin{array}{c}\text { Toplam hacim indeksi } \\
(\mathbf{m m})\end{array}$ & Pişme kaybı \\
\hline 0 & $84.00 \pm 1.00^{\mathrm{a}}$ & $2.74 \pm 0.03^{\mathrm{a}}$ & $125.17 \pm 4.12^{\mathrm{a}}$ & $267.00 \pm 5.96^{\mathrm{a}}$ & $12.22 \pm 0.66^{\mathrm{a}}$ \\
10 & $79.00 \pm 0.00^{\mathrm{b}}$ & $2.58 \pm 0.03^{\mathrm{b}}$ & $118.83 \pm 1.72^{\mathrm{b}}$ & $271.00 \pm 4.42^{\mathrm{a}}$ & $12.10 \pm 0.62^{\mathrm{a}}$ \\
20 & $76.00 \pm 1.73^{\mathrm{c}}$ & $2.47 \pm 0.08^{\mathrm{c}}$ & $116.67 \pm 2.73^{\mathrm{b}}$ & $261.16 \pm 21.49^{\mathrm{b}}$ & $12.07 \pm 0.60^{\mathrm{a}}$ \\
30 & $73.33 \pm 1.16^{\mathrm{d}}$ & $2.41 \pm 0.05^{\mathrm{c}}$ & $113.33 \pm 2.73^{\mathrm{c}}$ & $260.50 \pm 13.56^{\mathrm{b}}$ & $12.34 \pm 0.59^{\mathrm{a}}$ \\
\hline
\end{tabular}

${ }^{a-c}$ Çizelgede aynı sütunda aynı harfle gösterilen değerler arasındaki farklar 0.05 güven sınırına göre önemsizdir $(\mathrm{P}>0.05)$. Standart hata $( \pm \mathrm{SH})$. 
Incir Çekirdeği Ununun Mufinin Fiziksel, Kimyasal, Tekstürel ve Duyusal

Kalitesi Üzerine Etkisi

Çizelge 4. Mufinlerin fiziksel özelliklerine ait değerler

\begin{tabular}{lcccc}
\hline içU oranı (\%) & Simetri indeksi & Tekdüzelik indeksi & Üst büzülme değeri & Alt büzülme değeri \\
\hline 0 & $11.33 \pm 1.03^{\mathrm{b}}$ & $-1.83 \pm 2.23^{\mathrm{b}}$ & $7.00 \pm 1.55^{\mathrm{ab}}$ & $11.17 \pm 1.60^{\mathrm{a}}$ \\
10 & $13.67 \pm 1.37^{\mathrm{ab}}$ & $0.66 \pm 2.94^{\mathrm{a}}$ & $6.33 \pm 1.03^{\mathrm{b}}$ & $10.33 \pm 2.25^{\mathrm{ab}}$ \\
20 & $13.83 \pm 3.19^{\mathrm{ab}}$ & $-1.17 \pm 2.93^{\mathrm{a}}$ & $7.67 \pm 1.03^{\mathrm{ab}}$ & $9.67 \pm 2.58^{\mathrm{ab}}$ \\
30 & $15.33 \pm 2.66^{\mathrm{a}}$ & $-0.67 \pm 1.41^{\mathrm{a}}$ & $8.17 \pm 1.17^{\mathrm{a}}$ & $8.83 \pm 2.56^{\mathrm{b}}$ \\
\hline
\end{tabular}

a-c Çizelgede aynı sütunda aynı harfle gösterilen değerler arasındaki farklar 0.05 güven sınırına göre önemsizdir $(P>0.05)$. Standart hata $( \pm \mathrm{SH})$.

ettikleri mufinlerde spesifik hacim ve hacim değerlerinin kontrol örneğine göre azaldığını, 2.06-1.80 cm3/g arasında değiştiğini bildirmişlerdir.

Pişme kaybı değeri incelendiğinde, en yüksek pişme kaybı \%30 içU ilaveli mufinde (12.34) görülürken en düşük pişme kaybı \%20 içU ilaveli mufinde (12.07) bulunmuştur. Ipek (2017) tarafından yapılan çalışmada farklı formlarda yer fıstığının ilave edilmesiyle mufinlerde pişme kaybı azalmıştır. Pişme kaybı değerinin birim miktar undan yapılan hamur ve ekmek miktarının hesaplanmasında ve işletme açısından verimliliğin belirlenmesinde önemli bir ölçüt olup, değerin düşük olmasının istendiğini belirtmiştir. Keklerin üst kısımlarının yüzey profillerini belirlemek için kullanılan bir ölçüt olan simetri indeksinin pozitif bir değer alması kekin bombeli yani kabarık olduğunu, negatif bir değer alması ise kekin çöktüğünü gösterir (Giritlioğlu, 2017). IÇU ilavesi ile üretilen mufin örneklerinin simetri indeksi değerleri incelendiğinde $\% 20$ ve $\% 30$ oranında içU içeren mufinlerin simetri indekslerinin diğerlerine göre daha yüksek olduğu ve artan oranlarda içU ilavesinin mufinlerin daha bombeli olmasını sağladığı belirlenmiştir. Tekdüzelik indeksi, kekin yanal olarak simetrisini gösterir. Kek merkezine eşit uzaklıktaki 2 ayrı noktadan alınan bu ölçümlerin birbirine eşit olması yani bu indeks değerinin 0 olması istenir (İpek, 2017). Çizelge incelendiğinde içU içeren mufinlerin kontrol örneğine göre daha çok sıfıra yakın tekdüzelik indeksi değerine sahip oldukları, buna göre içU içeren mufinlerin kontrole göre daha iyi yanal simetrisi olduğu anlaşılmıştır. Elde edilen sonuçlar içu'nun \%30 gibi yüksek oranlarda kullanıldığında mufinlerin tekdüzelik indeksini olumsuz yönde etkilemediğini bu nedenle sanayi tipi mufin üretiminde yapısal bir fark oluşturmaksızın kullanılabileceğini göstermiştir.
Mufin kalıbına doldurulan hamurların alt taban çapında oluşan küçülmeyi ifade etmek için "alt büzülme değeri", üst çapında oluşan küçülmeyi ifade etmek için ise "üst büzülme değeri" ifadeleri kullanılır (Giritlioğlu, 2017). Değerlere bakıldığında mufine içU artan oranlarda ilave edildiğinde kontrol örneğine göre üst büzülme artmış, alt büzülme azalmıştır.

Üretilen mufin örneklerine ait bazı kimyasal özellikler Çizelge 5 'te verilmiştir. Çizelgeye göre en düşük nem ve kül değeri \%17.15 ve \%1.27 ile kontrol örneğinde, en yüksek nem ve kül değeri ise \%17.87 ve \%1.56 ile \%30 içU ilave edilen mufinde belirlenmiştir. içU oranı arttıkça nem ve kül değeri artmıştır. Protein değerlerinde en yüksek değeri kontrol örneğinde (\%13.35) belirlenmiştir. içU ilave edilen mufinlerde birbirlerine yakın değerler bulunmuştur. Yağ değerleri incelendiğinde en düşük değer \%34.7 ile \%10 içU ilave edilen mufinde, en yüksek değer \%37.67 ile kontrol örneğinde bulunmuştur. Yağ değerleri içU ilave edilen mufinler kontrol örneğine benzer sonuçlar vermiştir.

Diyet lif miktarlarına bakıldığında kontrol mufinde \%4.65 olan diyet lif değeri, içU ilave edilen mufinlerde sırasıyla \%6.67, \%10.64, \%13.58 değerlerini almıştır. IÇU oranı arttıkça yağ, protein ve diyet lif oranı artmıştır. Su aktivitesi (aw) değerleri içU oranı arttıkça artış göstermiştir. Noğay'ın (2014) farklı yöntemlerle elde ettiği nar çekirdeği tozlarını $\% 0, \% 10, \% 20, \% 30$ oranlarında ilave ettiği mufinlerde en yüksek değer \%30 nar çekirdeği tozu ilave edilen örnekte (\%12.53) bulunmuştur. Yağ değerlerinde en yüksek değerin \%30 nar çekirdeği ilaveli örnekte (\%32.43) olduğu belirlenmiştir. Yapılan bir çalışmada $\% 15$ ve $\% 30$ oranında Ayçiçek çekirdeği unu ilave edilen mufinlerin kontrol örneğine göre protein (\%7.13 ve \%8.20) ve yağ (\%7.55 ve \%8.13) değerleri artış göstermiştir. Su aktivitesi (aw) değeri ise azalmıştır (Grasso ve ark., 2020).

Çizelge 5. Mufinlerin kimyasal özelliklerine ilişkin değerler

\begin{tabular}{lllclcl}
\hline içU oranı (\%) & Nem (\%) & Kül (\%) & Protein (\%) & Yağ (\%) & Diyet lif (\%) & Su aktivitesi (aw) \\
\hline 0 & $17.15 \pm 0.17^{\mathrm{c}}$ & $1.27 \pm 0.14^{\mathrm{b}}$ & $13.35 \pm 0.01^{\mathrm{a}}$ & $37.67 \pm 0.10^{\mathrm{a}}$ & $4.65 \pm 0.00^{\mathrm{d}}$ & $0.76 \pm 0.02^{\mathrm{c}}$ \\
10 & $17.27 \pm 0.16^{\mathrm{bc}}$ & $1.41 \pm 0.04^{\mathrm{ab}}$ & $8.47 \pm 0.01^{\mathrm{d}}$ & $34.70 \pm 0.08^{\mathrm{c}}$ & $6.67 \pm 0.45^{\mathrm{c}}$ & $0.77 \pm 0.01^{\mathrm{b}}$ \\
20 & $17.75 \pm 0.15^{\mathrm{ab}}$ & $1.49 \pm 0.02^{\mathrm{a}}$ & $8.74 \pm 0.01^{\mathrm{c}}$ & $35.37 \pm 0.04^{\mathrm{bc}}$ & $10.64 \pm 0.28^{\mathrm{b}}$ & $0.79 \pm 0.02^{\mathrm{a}}$ \\
30 & $17.87 \pm 0.45^{\mathrm{a}}$ & $1.56 \pm 0.01^{\mathrm{a}}$ & $9.62 \pm 0.49^{\mathrm{b}}$ & $36.14 \pm 0.60^{\mathrm{b}}$ & $13.58 \pm 0.31^{\mathrm{a}}$ & $0.80 \pm 0.01^{\mathrm{a}}$ \\
\hline
\end{tabular}

$\overline{a, b, c}$ Çizelgede aynı sütunda aynı harfle gösterilen değerler arasındaki farklar 0.05 güven sınırına göre önemsizdir ( $P>0.05)$. Standart hata $( \pm \mathrm{SH})$. 


\section{Renk Değerleri}

Mufinlerin renk değerleri Çizelge $6^{\prime}$ da verilmiştir. Farklı oranlarda IÇU ilavesi mufin örneklerinin istatistiksel olarak kabuk renk değerlerinde yani $L, a$, ve $b$ değerlerinde önemli bir fark olmazken $(p>0,05)$, iç renk değerlerinde üzerinde önemli bir fark oluşturmuştur $(p<0.05)$. Kontrol örneğinde kabuk $L$ değeri 42.78 iken $\% 10, \% 20$ ve \%30 oranlarında içU ilave edilen örneklerde sırasıyla $40.71,37.37$ ve 34.69 değerlerini almıştır. İç renk $L$ değerine bakıldığında kontrol örneği 72.10, içU ilaveli mufinlerde sırasıyla 63.20, 56.14 ve 50.78 olmuştur. Yani içU ilavesi arttıkça mufinin kabuk ve iç renkte koyulaşma olmuştur. Bu renk değişimlerinin içU'nun lif içeriğinin yüksek olmasından (Chahed ve ark., 2018) ve pişirme sırasında şekerin karamelizasyonundan ve aminoasitler ile şekerler arasında meydana gelen Maillard reaksiyonundan kaynaklandığı düşünülmektedir (Demir, 2020).

iÇU oranının artmasıyla kabukta a ve b değerleri azalmıştır. Kabuk a ve b değerlerinde en yüksek değerler kontrol örneğinde (16.31 ve 19.96), en düşük değerler \%30 içU katkılı mufinlerde (13.66 ve 14.49) saptanmıştır. Yani kırmızılık ve sarılık azalmıştır. İç renk değerlerine bakıldığında a değeri artmış, b değeri azalma göstermiştir. içU ilavesinin renk değerleri üzerinde etkili olduğu görülmüştür. Akter ve Alim (2018) patates unu ve yer fıstığı unuyla yaptığı çalışmada patates unu arttıkça yer fıstığı unu azaldıkça keklerin renginin koyulaştığını bildirmişlerdir. Elde edilen değerler incelendiğinde içu ilavesiyle mufinlerin renk değerlerinde olumsuz bir etki oluşturmadığı ve fonksiyonel olarak üretilebileceği kanısına varılmıştır.

Tekstür Özelliklerine İlişkin Değerler

Farklı oranlarda içU ile üretilen mufinlerin tekstür özelliklerine ait değerler Çizelge 7'de verilmiştir. Çizelgedeki sertlik değerleri incelendiğinde en yüksek değer \%30 içU ilave edilen mufinde (939.3), en düşük değer \%10 içU ilave edilen mufinde (790.03) bulunmuştur. IÇU ilavesi arttıkça sertlik artmıştır. Matos ve ark. (2014) sertlik değerlerinin artmasını proteinlere bağlı olduğunu bildirmişlerdir. Esneklik değerleri içU oranının artmasıyla azalmıştır. En
ÖZKAN H, GÜL H yüksek değeri kontrol örneği alırken, en düşük değer \%30 IÇU katkılı mufinde olmuştur. Yapışkanlık değerlerine bakıldığında kontrol örneği 0.56 ile en yüksek değerde, \%30 IÇU ilave edilen mufin 0.50 ile en yüksek değerde olmuştur. Bir diğer ölçüt olan çiğnenebilirlik incelendiğinde değerleri incelendiğinde \%30 içU ilave edilen mufinin (387.77) diğerlerine göre daha kolay çiğnenebilir olduğu görülmüştür. Sakızımsılık değeri en yüksek \%10 içU katkılı mufin örneğinde (489.05) bulunmuş, içU ilavesi ile önemli düzeyde azalmıştır. içU oranı arttıkça sakızımsılık azalmıştır. \%10 içU ilave edilen mufinin daha sakızımsı yapıda olduğu görülmüştür. Mamat ve ark. (2018), yaptıkları çalışmada deniz yosunu oranı arttıkça sertliğin arttığını ve esnekliğin azaldığını belirtmişlerdir. Gomez ve ark. (2010), sertlik ve hacim arasında ters bir ilişki olduğunu bildirmiştir. Sıkılık değerlerine bakıldığında kontrol örneğinin içU katkılı mufinlere göre daha sıkı bir yapıda olduğu görülmüştür. Mufinlerde en düşük sıkılık değeri \%30 içU'lu mufinde belirlenirken, kontrol örneğine en yakın değer \%10 içU'lu mufinde bulunmuştur.

Tüm tekstür değerleri incelendiğinde \%20 düzeyine kadar içU katkısının tekstürel özellikleri olumlu yönde etkilediği \%30 gibi yüksek düzeye çıkıldığında ise bazı tekstürel değerlerin olumsuz etkilendiği saptanmıştır.

\section{Duyusal Özellikler}

Çizelge 8'de verilen değerler incelendiğinde içU ile üretilen mufinlerin sonuçlarının birbirine yakın olduğu, \%30 içU ile üretilen mufinin diğerlerine göre daha az beğeni aldığı görülmüştür. \%10 ve \%20 içU ile üretilen mufinlerin duyusal olarak yadırganmadığı, kontrol örneğine göre daha fazla beğenildiği, içU miktarının \%20'den fazla artmasıyla mufinin duyusal özelliklerinin azaldığı, \%30 ile üretilen mufinlerin daha az beğeni aldığı görülmüştür. \%20 içU ile üretilen mufinlerin daha fazla beğenildiği, aroma ve tat bakımından kontrol örneğine göre daha üstün olduğu belirlenmiştir. Tüketici beğenisi dikkate alındığında içU'nun mufin üretimine \%20'ye kadar ilave edilebileceği sonucuna varılmıştır.

Çizelge 6. Mufinlerin renk özelliklerine ait değerler

\begin{tabular}{lcccccc}
\hline iÇU oranı (\%) & \multicolumn{3}{c}{ Kabuk } & \multicolumn{3}{c}{ iç } \\
\hline 0 & $L^{*}$ & $a^{*}$ & $b^{*}$ & $L^{*}$ & $a^{*}$ & $b^{*}$ \\
10 & $42.78 \pm 2.76^{\mathrm{a}}$ & $16.31 \pm 0.31^{\mathrm{a}}$ & $19.96 \pm 1.78^{\mathrm{a}}$ & $72.10 \pm 2.79^{\mathrm{a}}$ & $-0.38 \pm 0.28^{\mathrm{d}}$ & $23.34 \pm 1.10^{\mathrm{a}}$ \\
20 & $40.71 \pm 1.30^{\mathrm{a}}$ & $16.25 \pm 0.55^{\mathrm{a}}$ & $18.68 \pm 0.76^{\mathrm{a}}$ & $63.20 \pm 1.50^{\mathrm{b}}$ & $3.92 \pm 0.16^{\mathrm{c}}$ & $19.78 \pm 0.57^{\mathrm{a}}$ \\
30 & $37.37 \pm 1.12^{\mathrm{b}}$ & $14.71 \pm 0.36^{\mathrm{b}}$ & $16.27 \pm 0.71^{\mathrm{b}}$ & $56.14 \pm 0.90^{\mathrm{c}}$ & $6.21 \pm 0.20^{\mathrm{b}}$ & $19.02 \pm 0.44^{\mathrm{a}}$ \\
\hline
\end{tabular}

$\overline{a, b, c}$ Çizelgede aynı sütunda aynı harfle gösterilen kabuk renk değerleri arasındaki farklar 0.05 güven sınırına göre önemsizdir (P>0.05). ${ }^{a-d}$ Çizelgede aynı sütunda aynı harfle gösterilen iç renk değerleri arasındaki farklar 0.05 güven sınırına göre önemlidir $(P<0.05)$. Standart hata $( \pm \mathrm{SH})$.

Çizelge 7. içU'nun mufinlerin tekstürel özellikleri üzerine etkisi

\begin{tabular}{lcccccc}
\hline $\begin{array}{l}\text { içU } \\
(\%)\end{array}$ & $\begin{array}{c}\text { Sertlik } \\
(\mathbf{g})\end{array}$ & Esneklik & $\begin{array}{c}\text { Yapışkanlık } \\
\text { (g×s) }\end{array}$ & Sakızımsılık & Çiğnenebilirlik & Sıkılık \\
\hline 0 & $878.39 \pm 37.02^{\mathrm{ab}}$ & $0.91 \pm 0.02^{\mathrm{a}}$ & $0.56 \pm 0.30^{\mathrm{a}}$ & $487.48 \pm 26.6^{\mathrm{a}}$ & $444.64 \pm 18.87^{\mathrm{a}}$ & $642.42 \pm 31.58^{\mathrm{a}}$ \\
10 & $790.03 \pm 10.52^{\mathrm{b}}$ & $0.90 \pm 0.03^{\mathrm{a}}$ & $0.54 \pm 0.44^{\mathrm{a}}$ & $489.05 \pm 28.7^{\mathrm{a}}$ & $434.62 \pm 16.39^{\mathrm{a}}$ & $563.10 \pm 29.10^{\mathrm{b}}$ \\
20 & $921.27 \pm 55.00^{\mathrm{a}}$ & $0.89 \pm 0.02^{\mathrm{a}}$ & $0.53 \pm 0.12^{\mathrm{b}}$ & $472.77 \pm 17.2^{\mathrm{a}}$ & $417.05 \pm 18.70^{\mathrm{ab}}$ & $562.04 \pm 13.71^{\mathrm{b}}$ \\
30 & $939.30 \pm 66.00^{\mathrm{a}}$ & $0.88 \pm 0.01^{\mathrm{a}}$ & $0.50 \pm 0.48^{\mathrm{b}}$ & $428.27 \pm 10.1^{\mathrm{b}}$ & $387.77 \pm 6.46^{\mathrm{b}}$ & $512.92 \pm 64.74^{\mathrm{b}}$ \\
\hline
\end{tabular}

a,b Çizelgede aynı sütunda aynı harfle gösterilen değerler arasındaki farklar 0.05 güven sınırına göre önemsizdir (P>0.05). Standart hata $( \pm \mathrm{SH})$. 
Incir Çekirdeği Ununun Mufinin Fiziksel, Kimyasal, Tekstürel ve Duyusal Kalitesi Üzerine Etkisi

Çizelge 8. Duyusal özelliklere ait değerler

\begin{tabular}{lccccccc}
\hline içU oranı (\%) & Dış renk & İç renk & Tekstür & Koku & Aroma & Tat & Genel beğeni \\
\hline 0 & $3.3 \pm 0.68^{\mathrm{b}}$ & $3.4 \pm 0.52^{\mathrm{b}}$ & $3.3 \pm 0.68^{\mathrm{a}}$ & $3.4 \pm 1.10^{\mathrm{a}}$ & $3.0 \pm 1.16^{\mathrm{b}}$ & $3.2 \pm 1.03^{\mathrm{a}}$ & $3.4 \pm 1.00^{\mathrm{a}}$ \\
10 & $4.3 \pm 1.25^{\mathrm{a}}$ & $3.8 \pm 1.32^{\mathrm{a}}$ & $3.8 \pm 0.92^{\mathrm{a}}$ & $3.8 \pm 1.23^{\mathrm{a}}$ & $4.3 \pm 0.68^{\mathrm{a}}$ & $3.8 \pm 1.23^{\mathrm{a}}$ & $3.9 \pm 1.30^{\mathrm{a}}$ \\
20 & $4.4 \pm 0.70^{\mathrm{a}}$ & $4.3 \pm 0.82^{\mathrm{a}}$ & $3.6 \pm 1.17^{\mathrm{a}}$ & $3.9 \pm 0.88^{\mathrm{a}}$ & $4.4 \pm 1.00^{\mathrm{a}}$ & $4.3 \pm 0.82^{\mathrm{a}}$ & $4.3 \pm 0.82^{\mathrm{a}}$ \\
30 & $2.4 \pm 1.17^{\mathrm{c}}$ & $2.6 \pm 1.27^{\mathrm{b}}$ & $2.6 \pm 1.28^{\mathrm{b}}$ & $2.5 \pm 1.08^{\mathrm{b}}$ & $3.1 \pm 1.20^{\mathrm{b}}$ & $3.3 \pm 1.34^{\mathrm{a}}$ & $3.3 \pm 0.95^{\mathrm{a}}$ \\
\hline $\mathrm{a}, \mathrm{b}, \mathrm{c}$
\end{tabular}

a,b,c Çizelgede aynı sütunda aynı harfle gösterilen değerler arasındaki farklar 0.05 güven sınırına göre önemsizdir $(P>0.05)$. Standart hata $( \pm \mathrm{SH})$.

\section{SONUÇ}

Mufin, birçok ülkede üretilen, besleyici değeri yüksek, göz ve damak zevkine hitap eden, farklı formülasyon ve şekillerde üretilen bir üründür. Dünyada ve Türkiye'de unlu mamuller arasında önemli yer tutar. Unlu mamuller arasında önemli bir yeri olan mufin üretimi de artmakta ve farklı formülasyon ve şekillerde üretilmeye devam etmektedir. İncir çekirdeği ununun mufine ilave edilmesiyle ürünün besin değerinin arttığı ve ürün kalitesinin geliştiği görülmüştür. Sonuç olarak incir çekirdeği ununun mufin üretiminde kullanılmasıyla fonksiyonel özelliklerinde iyileşmelerin sağlandığı belirtilmiş ve protein değeri, diyet lif oranı yüksek; üretimi kolay ve ucuz, besin değeri yüksek yeni bir ürün geliştirilmiştir. Tüketici açısından incir çekirdeği ununun \%20'ye kadar kabul edilebilir olduğu görülmüştür.

\section{TEŞEKKÜR}

$\mathrm{Bu}$ çalışma Süleyman Demirel Üniversitesi Bilimsel Araştırma Projeleri (SDÜ-BAP) Koordinasyon Birimi tarafından FYL-2019-6940 No'lu proje ile yüksek lisans tez çalışması kapsamında desteklenmiştir. Desteklerinden dolayı SDÜ-BAP birimine teşekkür ederiz.

\section{KAYNAKLAR}

AACC 10-91.01 (2000) Approved Methods of the American Association of Cereal Chemists 10th Edition. The Association St. Paul MN USA.

Akbaş Ö (2009) Mufin Üretiminde Ekzopolisakkaritlerin Kullanımı. Yüksek Lisans Tezi, Yüzüncü Yıl Üniversitesi, Van.

Akter N, Alim MN (2018) Preparation of Wheat-PotatoPeanut Composite Flour Cakes. Journal of Bangladesh Agricultural University 16(2): 315-321.

Anonim (2020) Bitkisel Üretim İstatistikleri. Meyveler İçecekler ve Baharat Bitkileri, Ankara. https://biruni.tuik.gov.tr/medas/?kn=88\&locale=tr (Erişim Tarihi: 09/06/2020)

AOAC (1990) Official Methods of Analysis 15th Edition Association of Official Analytical Chemists. Washington DC.

AOAC (2000) Official A.O.A.C. Methods of analysis 17th Edition Total Soluble and Insoluble Dietary Fiber in Foods Enzymatic Gravimetric Method MES-TRIS Buffer. Arlington VA.

Bajerska J, Gornas P, Seglina D, Mildner-Szkudlarz S (2016) The Effects of Muffins Enriched with Sour Cherry Pomace on Acceptability, Glycemic Response, Satiety and Energy Intake: A Randomized Crossover Trial. Journal of the Science of Food and Agriculture 96: 2486-2493.
Camire ME, Therrien M, Yerxa K, Mellette T (2018) Whole Grain Muffin Acceptance by Young Adults. Foods 91(7): 1-13.

Chahed A, Chaouch MA, Chouchéne $W$, Chahdoura $H$, Achour S, Adouni K, Mosbaha H, Majdoubb H, Flaminid G, Achour L (2018) Incorporation of Opuntia Macrorhiza Engelm. in Cake-Making: Physical and Sensory Characteristics. LWT - Food Science and Technology 90: 15-21.

Demir R (2020) Ekşi Hamur Tozu Kullanımının Kekin Kalite Özellikleri ve Raf Ömrü Üzerine Etkileri. Yüksek lisans tezi, Akdeniz Üniversitesi, Antalya.

Demirekin A (2019) Pirinç Nişastasından Çeşitli Yöntemler İle Elde Edilen Enzime Dirençli Nişastanın Karakterizasyonu Ve Ekmek Kalitesi Üzerine Etkisi. Yüksek lisans tezi, Süleyman Demirel Üniversitesi, Isparta.

Dizlek H, Altan A (2013) Pişirme Öncesinde Hamurun Kısa Süre Bekletilmesinin Pandispanya Nitelikleri Üzerine Etkisi. GIDA 38(1): 31-38.

Frank D, Kaczmarzka KT, Chandra-Hioe MV, Arcot J (2018) Enhancing Wheat Muffin Aroma Through Addition of Germinated and Fermented Australian Sweet Lupin (Lupinus angustifolius L.) and Soybean (Glycine max L.) Flour. LWT- Food Science and Technology 96: 205214.

Giritlioğlu E (2017) Kinoa (Chenopodium quinoa wild.) ve Şeker Otu (Stevia rebaudiana bertoni) Kullanılarak Yeni Bisküvi ve Kek Formülleri Geliştirme Üzerine Bir Araştırma. Yüksek Lisans Tezi, Osmaniye Korkut Ata Üniversitesi, Osmaniye.

Gomez M, Ruis-Paris E, Oliete B, Pando V (2010) Modelling of Texture Evolution of Cakes During Storage. Journal Texture Studies 41: 17-33.

Grasso S, Liu S, Methven L (2020) Quality of Muffins Enriched with Upcycled Defatted Sunflower Seed Flour. Food Science and Technology 119: 1-6.

Gupta RK, Goswami D, Mridula D, Sharma M, Tyagi TK (2015) Barnyard Millet Based Muffins: Physical, Textural and Sensory Properties. LWT-Food Science and Technology 64: 374-380.

Heo Y, Kim MJ, Lee JW, Moon B (2019) Muffins Enriched with Dietary Fiber from Kimchi By-Product: Baking Properties, physical-chemical properties, and consumer acceptance. Food Science and Nutrition 7: 1778-1785.

Herranz B, Canet W, Jimenez MJ, Fuentes R, Alvarez MD (2017) Characterisation of Chickpea Flour-based Gluten-free Batters and Muffins with Added 
Biopolymers: Rheological, Physical and Sensory Properties. International Journal of Food Science and Technology 51: 1087-1098.

İpek T (2017) Farklı Form ve Oranlarda Yerfıstığı Ürünleri Kullanılarak Ev ve Sanayi Tipi Mufin Üretiminin Optimizasyonu. Yüksek Lisans tezi, Osmaniye Korkut Ata Üniversitesi, Osmaniye.

İpek T, Dizlek H (2018) Farklı Form ve Oranlarda Yerfıstığı Ürünleri Kullanılmasının Top Kek Kalitesine Etkisi. GIDA 43(4): 591-604.

Llorca E, Diez-Sanches E, Quiles A, Reißner AM, Struck S, Rohm H, Hernando I (2019) Extruded Flour as Techno-Functional Ingredient in Muffins with Berry Pomace. LWT- Food Science and Technology 113: 1-8.

Mamat H, Akanda JMH, Zainol MK, Ling YA (2018) The Influence of Seaweed Composite Flour on the Physicochemical Properties of Muffin. Journal of Aquatic Food Product Technology 27(5): 635-642.

Matos ME, Sanz T, Rosell CM (2014) Establishing the Function of Proteins on the Rheological and Quality Properties of Rice Based Gluten Free Muffins. Food Hydrocolloids 35: 150-158.

Noğay O (2014) Farklı Yöntemlerle Elde Edilen Nar Çekirdeği Tozlarının Mufinin Mufin Kalite Özeliklerine Etkisi. Yüksek Lisans Tezi, Pamukkale Üniversitesi, Denizli.

Ödeş N (2018) Farklı Oranlarda Üzüm Çekirdeği İçeren Ekmeklerin Ekmek Verimi ve Kalitesini Glikoz Oksidaz ile İyileştirme İmkânlarının Araştırılması. Yüksek Lisans Tezi, Süleyman Demirel Üniversitesi, Isparta.

Pereiraa C, López-Corralesa M, Serradillac MJ, Villalobosb MC, Ruiz-Moyanob S, Martínb A (2017) Influence of
ÖZKAN H, GÜL H

Ripening Stage on Bioactive Compounds and Antioxidant Activity in Nine Fig (Ficus carica L.) Varieties Grown in Extremadura. Spain Journal of Food Composition and Analysis 64: 203-212.

Pineda MM, Antoniewska A, Adamska A, Rutkowska J (2018) Antioxidative, Nutritional and Sensory Properties of Muffins with Buckwheat Flakes and Amaranth Flour Blend Partially Substituting for Wheat Flour. Food and Science Technology 89, 217-223.

Taş EN (2019) Biochemical Characterization of Fig (Ficus carica L.) Seeds. Journal of Agriculture Science 25: 232-237.

Ulutürk Ş (2018) Incir Çekirdeği Unu Kullanılarak Glutenli ve Glutensiz Bisküvi Üretimi. Yüksek Lisans Tezi, Süleyman Demirel Üniversitesi, Isparta.

Vella D, Padhi EMT, Ramdath DD, Carson SJ, Hawke A, Blewett HJ, Wolever TMS, Seetharaman K, Duizer LM, Duncan AM (2015) Liking of Soy Flour Muffins Over Time and The İmpact of A Health Claim on Willingness to Consume. Food Research International 77: 491497.

Yadav SK, Sangwan RS, Prasad P, Mehta D (2018) Tomato Processing Byproduct Valorization in Bread and Muffin: İmprovement in Physicochemical Properties and Shelf Life Stability. Journal Science and Technology 55(7): 2560-2568.

Yazıcı AS (2016) Taze ve Kuru İncir Çekirdeklerinin Fiziksel ve Kimyasal Kompozisyonları. Yüksek Lisans Tezi, Afyon Kocatepe Üniversitesi, Afyon. 
